INSTITUTO HISTÓRICO E GEOGRÁFICO BRASILEIRO

GUSTAVO PEREIRA

\title{
HOMENS DO FUTURO, DO PRESENTE E DO PASSADO EM COMEMORAÇÕES HISTÓRICAS - PORTUGAL E BRASIL, SÉCULO XIX
}

PEREIRA, Gustavo HOMENS DO FUTURO, DO PRESENTE E DO PASSADO EM COMEMORAÇÕES HISTÓRICAS - PORTUGAL E BRASIL, SÉCULO XIX

R. IHGB, Rio de Janeiro, a. 180(481): 123-152, set./dez. 2019 


\title{
HOMENS DO FUTURO, DO PRESENTE E DO PASSADO EM COMEMORAÇÕES HISTÓRICAS - PORTUGAL E BRASIL, SÉCULO XIX
}

\author{
MEN FROM THE FUTURE, OF THE PRESENT AND FROM THE \\ PAST IN HISTORICAL CELEBRATIONS - PORTUGAL AND \\ BRAZIL, 19TH CENTURY
}

Gustavo Pereira ${ }^{1}$

\begin{abstract}
Resumo:
Busca-se refletir sobre como, em Portugal e no Brasil, lidou-se no século XIX com comemorações em torno de homens e de episódios de relevo - maneira peculiar de narrar o passado. Remonta-se ao início da década de 80 , quando houve celebrações centenárias (como a pombalina) nos dois lados do Atlântico, e recua-se às décadas de 20 e 30 , quando se estabeleceram e atualizaram festividades relacionadas a D. Pedro (I do Brasil, IV de Portugal), apreciado, de diferentes maneiras, ao longo do tempo.
\end{abstract}

Palavras-chave: História; Memória; Comemorações.

\section{Abstract:}

This paper is an attempt to understand how celebrations of important individuals and episodes of the past were perceived in 19th century's Portugal and Brazil - a peculiar way of narrate the past. It takes in consideration the early 1880s, when centenaries celebrations (such as the one commemorating Pombal), were held on both sides of the Atlantic, and goes back to the 1820s and 1830s, when festivities were established and continuously updated around different perceptions regarding D. Pedro (I of Brazil, IV of Portugal), a man appreciated in diferent ways over time.

Keywords: History; Memory; Celebrations.

Nós, os homens do futuro

[...] herdeiros e discípulos

De Camões e de Pombal Empunhando a pena ou a espada Honraremos Portugal. Hino dos estudantes (1882)

\section{Do passado, do presente}

Ao longo do Oitocentos, discutiam-se, no Instituto Histórico e Geográfico Brasileiro (IHGB), fundado em 1838, parâmetros para a história nacional que se pretendia afirmar para o Império do Brasil (1822-1889).

1 - Assistente de Investigação. CHAM - Centro de Humanidades. Universidade Nova de Lisboa. 
Abordava-se a história enquanto discurso crítico e disciplinado sobre determinados acontecimentos pretéritos; enquanto discurso elaborado a partir de vestígios do passado percebido como brasileiro - tornados documentos mediante suas seleção, recuperação e preservação (atividades a que muito se dedicaram os homens do Instituto) ${ }^{2}$. No programa do IHGB coetâneo, nota-se a importância da escrita biográfica como forma de resgatar e de preservar do esquecimento individualidades relevantes para a narrativa nacional que se buscava consolidar³ ${ }^{3}$ Nota-se, também, a afirmação do distanciamento temporal como condição para a justa apreciação desse passado - o que implicava desconfiar de reflexões sobre temáticas mais ou menos contemporâneas e polêmicas ${ }^{4}$.

Na Sessão Magna Aniversária do Instituto, celebrada em 1881, Franklin Távora (1842-1888) discursou, homenageando seus consócios recém-falecidos. Diferenciando o ato que protagonizava do "espetáculo no seio da família por ocasião dos aniversários do falecimento das suas

2 - Ver os verbetes "história", "memória" e "documento/monumento". LE GOFF, J. História \& Memória. Campinas: Unicamp, 2014 [1990]. Considerando a polissemia da palavra história, pode-se afirmar que se coligiam documentos que permitissem, nas condições e nos momentos devidos, avaliar criticamente a história (acontecimentos passados). Buscava-se, ademais e como parte desse esforço, preservar memórias (recordação; narrativa afetiva, mítica e eficaz do passado), que tanto poderiam ser objeto da história (crítica, historiografia), quanto poderiam ser mobilizadas politicamente, pela via dos sentimentos que evocavam (como nas comemorações). Para Lúcia Guimarães (que resgata a oposição história-memória a partir de Pierre Nora), produziu-se no IHGB memória, e não história. GUIMARÃES, L. M. P. "Debaixo da imediata proteção de Sua Majestade Imperial: o Instituto Histórico e Geográfico Brasileiro (1828-1889)”, R.IHGB, n. 88, 1995. Ver ainda: GUIMARÃES, M. L. S. "Nação e civilização nos trópicos: o Instituo Histórico e Geográfico Brasileiro e o projeto de uma História Nacional”, Estudos Históricos, n. 1, 1988. 3 - ENDERS, A. “'O Plutarco Brasileiro'. A produção dos vultos nacionais no Segundo Reinado". Estudos Históricos, Rio de Janeiro, n. 25, 2000; OLIVEIRA, M. G. "Brasileiros ilustres no tribunal da posteridade: biografia, memória e experiência da história no Brasil oitocentista". Varia História, Belo Horizonte, v. 26, n. 43, 2010.

4 - Havia, no Instituto, demandas por uma escrita do presente, mas, a par de iniciativas não-continuadas nesse sentido (armazenadas para a apreciação de historiadores futuros), houve outras em sentido oposto, como a arca do sigilo (para arquivar de documentação e temáticas cuja apreciação era considerada inconveniente no presente, sendo por isso legadas ao tribunal da posteridade). Afirmou-se, assim, o preceito do distanciamento temporal. MALEVAL, I, I. Entre a "arca do sigilo" e o "tribunal da posteridade": o (não) lugar do presente nas produções do Instituto Histórico e Geográfico Brasileiro (18381889). Tese de Doutorado, História. Rio de Janeiro: PPGH-UERJ, 2015. 
pessoas caras", ele aponta que, distintamente das ausências recordadas no ambiente familiar, no IHGB

os evocados volvem às nossas relações como se entre eles e nós nunca se tivesse interposto o verme sepulcral. [...] Eles estão aqui no nosso grêmio - eles, os nossos amigos, que andavam ausentes e pareciam esquecidos de nós.

Desta vez, porém, não vêm conferir louros literários como era costume antes desse longo apartamento. Vêm, ao contrário, recebê-los de nossas mãos, porque são eles o objeto da nossa festa, são eles os laureados e somos nós que os galardoamos, nós que representamos neste momento a primeira entrância da posteridade .

Alguns anos antes, Joaquim Manoel de Macedo (1820-1882) estabeleceu, na celebração de 1863, uma distinção elucidativa sobre como se lidava no Instituto com algumas dessas questões:

o elogio acadêmico de um finado não pode ser uma biografia escrita com a severidade dos preceitos da história, porque nessa somente deve falar a justiça e naquela podem desafogar-se a estima e a saudade; em uma, a imparcialidade sentencia, no outro, a gratidão paga um tributo; sentença e tributo, porém, que são igualmente generosos e nobres quando nascem da consciência e firmam-se na verdade. [...] A família que em vestes de luto visita a sepultura onde um dos seus descansa dormindo o sono da morte, lembra saudosa os dotes e o merecimento do parente perdido e, ou não recorda seus erros, ou, se os recorda, desculpa-os. A família não julga, louva.

E como a família, o Instituto Histórico e Geográfico Brasileiro, comemorando anualmente aqueles que passaram à eternidade, paga uma dívida sagrada de reconhecimento e recordação das virtudes e dos serviços desses beneméritos [...]. No grande tribunal da história, os contemporâneos dos varões notáveis são apenas testemunhas e o juiz é somente a posteridade. [...] Comemoremos, pois, os nossos finados. Fale a verdade no elogio deles, e basta ${ }^{6}$.

Recuperando suas palavras, entende-se melhor a indicação de Távora dos elogios/tributos fúnebres (metafórica ressurreição, resgatando recém-falecidos do esquecimento) como "primeira entrância na posteridade".

5 - R.IHGB, Rio de Janeiro, t. 44, pt. II, 1881, p. 451-452. Grifos meus.

$6-$ R.IHGB, t. 26, 1863, p. 925-926. 
Para Macedo, dada a proximidade (afetiva e temporal) evocada, trata-se de um testemunho ao tribunal da história (registrando sua recordação), e ainda não de seu veredito (etapa futura). Se aos contemporâneos cabia deixar depoimentos verdadeiros aos homens do futuro (preservando do esquecimento indivíduos e acontecimentos), a esses caberia apreciar tais declarações com distanciamento temporal e método, julgando-as "com a severidade dos preceitos da história".

Távora também pondera sobre a relação entre a crítica da posteridade (de que resulta uma história-julgamento em constante reformulação) e as diferentes apreciações/vereditos sobre personagens históricas (biografias, não elogios) já operadas no país, revendo-se aspectos e protagonismos de narrativas do passado nacional a partir de um esclarecimento sobre acontecimentos pretéritos:

a crítica histórica, ainda que muito longe do lugar que lhe compete em nosso meio literário, tem mudado velhos pontos de vista, de onde até certo tempo foi apreciada a formação da nossa nacionalidade. [...] quanto mais nos adiantamos no estudo das nossas origens históricas, quanto mais penetra na cripta do nosso passado político a luz indiscreta, inconveniente, talvez, da crítica moderna, mais diminuem as proporções de certos vultos que chegaram ao nosso tempo a modo de envolvidos nos fumos da lenda.

Os nossos primeiros historiadores sofrem cada dia uma nova retificação. Os heróis que ostentam grandes estaturas nas páginas dos seus livros mostram-se figuras banais, sem grandes paixões e movem-se por pequenos caprichos e ambições vulgares nas páginas dos que vamos escrevendo. E por outro fenômeno paralelo, posto que contrário àquele, individualidades que esses escritores deixaram esquecidas e ocultadas nos recantos mais escuros dessa cripta insondável vão surgindo à luz e avultam de dia a dia como os verdadeiros beneméritos, os verdadeiros fundadores da nacionalidade [de] que desfrutamos. ${ }^{7}$

Quase à mesma altura, mas do outro lado do Atlântico, Jayme de Séguier (1860-1932) publica, em um jornal republicano, uma crônica sobre um tributo fúnebre em Lisboa:

7 - R.IHGB, t. 44, 1881, pt. II, p. 456-457. Grifos meus. 
ouvi na rua um clangor de clarins. Era um regimento de lanceiros que passavam [...]. A fanfarra entoava uma marcha de um movimento marcial e ingênuo. A voz dos clarins cantava com uma vibração sinistra $[\ldots]$.

Logo em seguida, desfilaram dois regimentos de cavalaria. Saí e encontrei pelas ruas as longas tênias dos grêmios de instrução e dos asilos de beneficência. Os pequerruchos marchavam dois a dois, a carita no ar, rindo de quem passava, completamente inconscientes da intenção do ato que iam praticar [...] fazia um singular contraste a ideia lúgubre daquela manifestação com a alegria ingênua e infantil de todos aqueles rostos imberbes e rosados.

Quanto ao motivo do ritual, supostamente ignorado pelos infantes, ele diz: "todo esse movimento indicara já a tarja preta do Diário do Governo. É hoje o vigésimo aniversário da morte de D. Pedro V". A cerimônia recorda outro momento do calendário lúgubre português, dedicado a um monarca homônimo: D. Pedro IV (de Portugal, I do Brasil), que "ainda arrasta à igreja todo o esplendor oficial um dia a cada ano. E não há jornal monárquico que não tenha no seu alforje algum lugar-comum, com perpétuas em bom estado, para depor sobre a capa do dador [da Carta de 1826], numa certa manhã de setembro"8.

À época, considerava-se feriado o dia que assinalava a morte do monarca anterior ao corrente - no caso, D. Pedro V (1853-1861), irmão e antecessor de D. Luís (1861-1889). O luto pelo aniversário fúnebre de D. Pedro IV, contudo, manteve-se até fins do período monárquico-constitucional/liberal (1820-1910), visando à conservação de sua memória como afirmação do regime ${ }^{9}$. Entende-se, assim, que Ramalho Ortigão (18361915), no mesmo ano, critique satiricamente defasagem de sentido no referido rito, dada a passagem do tempo:

de cada vez que vem ao mundo o dia 24 de setembro, o país cobre-se de crepes e arranca do seu peito um ai decretado no Diário [do governo]. Encerram-se as repartições públicas. As tropas vestem o grande uniforme e trazem as armas em funeral. O pavilhão nacional tremula

8 - A Folha Nova (1881-1888), Porto, 12/11/1881.

9 - ANDRADE, L. O. \& CATROGA, L. R. Feriados em Portugal: tempos de memória e de sociabilidade. Coimbra: Universidade de Coimbra, 2012, p. 62. 
a meio pau nas fortalezas e nos navios de guerra. A corte, os funcionários públicos, a nobreza e o corpo diplomático recolhem-se nos templos a orar. Os órgãos das igrejas e os artigos de fundo dos jornais entoam o De profundis e pregadores régios [...] sobem aos púlpitos tomados à hora para espargirem pitadas de latim e de rapé sobre a memória do morto.

- Por que, oh céus, uma tão grande dor?

- Porque Pedro morreu.

[...] Essa saudade pungente que nos devora uma vez por ano recai sobre um sujeito que morreu há cerca de meio século; que ninguém da nossa geração teve a honra de conhecer pessoalmente e que ninguém viu mais gordo.

Tudo quanto a retórica da indiferença, tudo quanto a ênfase da hipocrisia pode inspirar em nénias, em sermões e em artigos bombásticos se tem atirado para cima da cabeça desse morto. Nenhuma outra memória tem sido mais horrorosamente inundada de tudo quanto há de mais pinga, de mais sarrafaçal - e de mais reles nas ejaculações da literatura pelintra.

É talvez tempo de se pedir para Pedro o respeito do esquecimento, a consideração do silêncio.

Basta de exéquias! Basta de discursos!

Como rei, Pedro merecia decerto que o enterrássemos um pouco mais do que se enterra a outra gente. Como homem, ele começa, porém, a ter direito à nossa piedade. Calemo-nos. Sejamos humanos! $!^{10}$.

D. Pedro IV morreu em 24 de setembro de 1834, aos 36 anos - pouco após a assinatura, em Évora Monte, do documento que pôs termo à guerra civil (1832-1834) que opôs liberais e miguelistas em Portugal, com a vitória dos primeiros. Como liderança militar, associou-se fortemente ao restabelecimento do regime monárquico liberal no país, afirmado na Carta Constitucional por ele outorgada (no Brasil, para Portugal) em 1826 e restaurada com o fim do intervalo absolutista sob D. Miguel (1828-1834). Sua memória esteve, portanto, relacionada a uma heroicidade fundadora e unificadora, reunindo correntes liberais divergentes.

10 - O António Maria (1879-1898), Lisboa, 29/09/1881. 
Morreu relativamente cedo e, ainda em vida, presenciou oposições, mas a morte teve o efeito de poupar e de desculpar sua figura. Dado o que seu histórico evocava em Portugal, entende-se o empenho em eternizar as recordações a seu respeito. Empenho, contudo, que, afirmado o regime e reavivadas as oposições no seio dos liberais (que incidiam sobre a apropriação e sobre a gestão de seu legado), paulatinamente, esmoreceu. Disso, são demonstrações tanto os atrasos na inauguração de monumentos em sua homenagem quanto a relativa indiferença a cerimônias fúnebres em sua memória ${ }^{11}$.

Sobre seu neto D. Pedro V, diz Séguier, que dele ficou uma lembrança "bem idealmente simpática". Ele deixou "uma espécie de lenda que envolve a sua recordação num adorável luar". Morreu também prematuramente, em 11 de novembro de 1861 (aos 24 anos), sendo logo objeto de textos e de rituais laudatórios que excediam os do costume no liberalismo. Despertou um sentimento de perda, associado à idealização de sua figura. Demarcando-se da ideia que se fazia da família real, conservou-se sua imagem como inteligente e honesto, que se interessava por fazer o país progredir ${ }^{12}$.

Daí as palavras do cronista, que podem soar contraditórias: "esse homem excepcional teve uma única felicidade na terra - morrer cedo [...] entre saudades e bênçãos". Tivesse sobrevivido por mais tempo,

veriam como o cristal se rachava de alto a baixo com a pedrada de injúrias que ferve aí agora, pelas encruzilhadas da imprensa. Veriam como o seu manto se mosqueava de nódoas obscenas [...]. Veriam como a lenda se transformava em paródia.

Justifica-se e critica-se o tributo ao monarca falecido: "sua figura doce e poética vive decerto na saudade de muitos. É, todavia, um vulto apenas esboçado, de linhas hesitantes e sem a robustez necessária para resistir à luta pela existência histórica". Seriam bem poucos "os nomes que a história conserva", mas muitos os que "se perdem no esquecimento

11 - CATROGA, F. “O culto cívico de D. Pedro IV e a construção da memória liberal”. Revista de História das Ideias, Coimbra, n. 12, 1990.

12 - MÓNICA, M. F. D. Pedro V. Sintra: Temas e Debates, 2007, p. 07, 255-273. 
anônimo, essa segunda e mais irremediável morte”. Ao julgamento da posteridade, portanto (e não a inócuas cerimônias oficiais em torno de sua memória), caberia a sentença definitiva quanto à conservação e ao esquecimento dos indivíduos na história ${ }^{13}$.

Às homenagens aos Pedros IV e V, Séguier opõe criticamente o fato de que "o aniversário da morte de [Almeida] Garrett" (1799-1854), que se daria em pouco tempo (nove de dezembro), "passa despercebido nas regiões oficiais", o que lhe permite concluir que, como não se viam planos para comemorações ${ }^{14}$, "o século XIX lega ao século XX a herança de glorificar este nome no seu primeiro centenário. Acha que é bastante celebrar estes grandes nomes de cem em cem anos". Além disso, "o $1^{\circ} \mathrm{e}$ o $2^{\circ}$ aniversários [13 de setembro] da morte de [Alexandre] Herculano [1810-1877] passaram também na mesma obscuridade e olvido". O que o leva a afirmar que

as glórias mais puras, as inteligências mais vastas, os corações de ouro mais puro vão caindo pouco a pouco, fulminados pela morte, e o país, que vive do patrimônio da sua glória, não tem manifestações de saudade e de respeito senão para a memória dos seus reis ${ }^{15}$.

Ele não questiona o fato de haver manifestações em tributo aos mortos. A recordação e o reconhecimento de grandes individualidades falecidas são, para ele, um dever. Por isso, não os celebrando logo, legava-se tal obrigação aos homens do futuro - que pagariam tal dívida, herdada do século XIX, ritualizando efemérides ${ }^{16}$ centenárias. O que ele reprova é a 13 - O António Maria, 29/09/1881.

14 - As comemorações podem ser entendidas como ritualizações de aspectos do passado, cuja encenação visa à recordação e à educação (pela memória), enquanto rituais cívicos relacionam-se à transferência de sacralidade. Se sua intenção inicial é unir a coletividade (memorar junto) em torno de uma mensagem/identidade, revelam-se foco de uma série de disputas. COTTRET, B. \& HENNETON, L. "La commémoration, entre mémoire prescrite et mémoire proscrite". Du bon usage des commémorations. Rennes: PUR, 2010, p. 07-15.

15 - A Folha Nova, 12/11/1881.

16 - Efeméride enquanto fato importante ou grato que ocorreu em determinada data; comemoração de um fato importante, de uma data etc. (Dicionário Houaiss da Língua Portuguesa. Rio de Janeiro: Objetiva, 2001). Para uma reflexão histórica sobre a palavra: BONALDO, R. B. Comemoração e efemérides: ensaio episódico sobre a história de dois paralelos. Tese de Doutorado, História. Porto Alegre: UFRGS, 2014, p. 14. A aproxima- 
falta de critério adequado na avaliação quanto a quem seriam devidas as consagrações realizadas pelo país e o registro na história nacional ${ }^{17}$.

Para Séguier, não se deveria homenagear/recordar/conservar a figura histórica dos monarcas (irrefletidamente, por hereditariedade/tradição), e sim a de cidadãos defuntos cujos méritos passados, avaliados pela crítica histórica, assim o justificassem. Entre esses, ele destaca Garrett e Herculano - grandes escritores e representantes do primeiro romantismo liberal que lutaram contra os miguelistas ao lado de D. Pedro IV, desempenhando relevante papel nos cenários cultural e político. Séguier (republicano) opõe o vulto dos reis, "já meio indeciso e meio apagado na bruma do tempo" (mas cujas memórias seguiam mobilizadas pela pompa oficial, nas ruas e na imprensa, a despeito do que Ortigão aponta como "retórica da indiferença") ao semblante "clássico e escultural" de Garrett, à figura "gigante e hercúlea" de Herculano. E pergunta: "qual dos quatro se impõe mais à saudade vindoura? Qual [...] merece mais magnificentes exéquias?", propondo:

celebremos as mansas e boas virtudes, mas não esqueçamos as virtudes heroicas e fortes. Demos o nosso pensamento a um rei que foi bondoso. [...] Demos o nosso entusiasmo, o melhor grito do nosso coração, a um plebeu que foi sublime.

Oponhamos a nossa iniciativa popular às manifestações oficiais. Se a Sé se enche hoje de fardas bordadas e o ar se impregna de incenso, vamos nós em outras datas saudosas, com o nosso humilde fato preto, aos cemitérios onde dormem aqueles que o nosso espírito ama. Deixemos que nas folhas oficiais desabrochem portarias, regulando a festa fúnebre. Façamos nós sobre essas campas queridas desabrochar montanhas de rosas! ${ }^{18}$.

ção dos dois termos enquanto "sinônimos imperfeitos" (e a possibilidade de se enunciar a frase "comemorar efemérides") se dá apenas no final do século XIX, datando do século XX sua dicionarização enquanto sinônimos.

17 - Sobre comemorações à altura: CATROGA, F. "Ritualizações da História", In: TORGAL, L. R.; MENDES, J. A. \& História da História em Portugal. Séculos XIX-XX. Lisboa: Temas \& Debates, 1998 [1996]; MARCELINO, D. A. "Rituais políticos e representações do passado: sobre os funerais de 'homens de letras' na passagem do império à república". Tempo, Niterói, v. 22, n. 40, 2016.

18 - A Folha Nova, 12/11/1881. A peregrinação aos cemitérios era importante ritual (republicano) em finais do século XIX. CATROGA, F. O céu da memória: cemitério român- 
O caso de D. Pedro é interessante para refletir sobre a mobilização de memórias e de diferentes perspectivas acerca do passado em comemorações no século XIX dos dois lados do Atlântico. Ele foi imperador do Brasil: D. Pedro I (1822-1831) e rei de Portugal e Algarves: D. Pedro IV (1826) - onde foi também regente: duque de Bragança (1831-1834). Perpetuado em monumentos no Rio de Janeiro (1862), no Porto (1866) e em Lisboa (1870), sua figura passou por atualizações historiográficas (retificações e mudanças de ponto de vista, nas palavras de Távora) ligadas ao constitucionalismo e ao nacionalismo nos dois países. Legou seu coração ao Porto, onde ainda hoje se preserva (na igreja de Nossa Senhora da Lapa). Quanto ao restante de seu corpo, após um tempo em São Vicente de Fora, em Lisboa (panteão dos Bragança), encontra-se, desde 1972, em um monumento às margens do riacho do Ipiranga, em São Paulo, para onde foi trasladado após negociações entre os governos português e brasileiro quando da comemoração dos 150 anos da independência ${ }^{19}$.

No que diz respeito ao Brasil, importa pensar sua figura desde o pós-independência (1822). Na narrativa nacional que então se conformava, afirmaram-se como marcos quatro episódios relacionados à trajetória do príncipe herdeiro português proclamador da independência: o Dia do Fico (nove de janeiro de 1822), o Grito do Ipiranga (sete de setembro de 1822), sua aclamação como D. Pedro I, imperador constitucional e protetor perpétuo do Brasil (12 de outubro de 1822, também seu aniversário) e a outorga da Constituição (25 de março de 1824). Inicialmente, não havia definição sobre quando comemorar a fundação do Império, mas se fixaram essas datas no calendário de festividades cívicas, ao qual ainda se adicionou uma quinta: a abertura do parlamento (três de maio, segundo a constituição $)^{20}$. Tal calendário estabeleceu-se ainda na primeira sessão da

tico e culto cívico dos mortos em Portugal (1756-1911). Coimbra: Minerva, 1999, cap. V. 19 - O monumento foi inaugurado para o centenário da independência (1922), mas concluído apenas em 1926. O traslado deu-se na efeméride seguinte, quando os restos fúnebres percorreram o país. CORDEIRO, J. M. Lembrar o passado, festejar o presente: as comemorações do Sesquicentenário da Independência entre consenso e consentimento (1972). Tese de Doutorado, História. Niterói: PPGH-UFF, 2012.

20 - KRAAY, H. Days of national festivity in Rio de Janeiro, Brazil, 1823-1889. Stanford: Stanford University, 2013, p. 13-30. 
primeira legislatura, em 1826. Contudo, o imperador, em 21 de dezembro de 1822, havia decretado uma primeira listagem com dias de gala ${ }^{21}$.

A discussão no parlamento colocou em pauta diferentes perspectivas acerca da narrativa nacional, das comemorações oficiais e de sua função $0^{22}$. De acordo com o visconde de Nazaré (1774-1827), autor da proposta, "todas as nações recomendaram sempre à posteridade os dias notáveis de suas instituições; aqueles em que se praticaram certos fatos de grandeza e heroísmo que as tornaram célebres à face do mundo". O senador ainda aponta que "nós também temos certos dias de igual notabilidade". Sendo já declarados dia de gala pelo referido decreto imperial, fazia-se necessário declará-los "de festa nacional [...] de regozijo público em todo o império".

Sua ideia contemplava sete dias e foi criticada pelo visconde de Barbacena (1772-1842), para quem "se nós quisermos fazer um projeto de festas nacionais de todos os acontecimentos memoráveis, teremos o inconveniente de, em pouco tempo, metade do ano ser toda de festas, além de que todos os objetos mais estimáveis, quando se multiplicam, perdem todo o seu valor". Como quase todos os dias sugeridos eram "de um só homem", seria "melhor que reuníssemos todos em um só, que é o dia 12 de outubro, que deu ao mundo o imperador que declarou a independência e efetuou a fundação do império"23.

Partindo de um rol comum de datas, debatiam-se seu número e a qual/quais atribuir prioridade. Para alguns, como o visconde de Carave-

21 - O decreto estabelecia nove dias de grande gala e nove de pequena gala, sobretudo de teor religioso e relacionados à família imperial - com exceção do dia da proclamação do sistema constitucional (26 de fevereiro). Da listagem referida, constava apenas o 12 de outubro, sem menção ao sete de setembro. Collecção das leis do Imperio do Brazil de 1822, v. I, pt. II. Rio de Janeiro, 1887.

22 - O projeto foi apresentado no senado em 20 de junho, passou por três discussões e foi aprovado em 17 de julho, sendo então remetido à câmara dos deputados - onde se deu a inclusão do três de maio; "dia em que o Brasil viu pela primeira vez a nação reunida e legitimamente representada" (Teixeira de Gouveia, Annaes do Parlamento Brazileiro, t. III, 1826. Rio de Janeiro, 1874).

23 - Annaes do Senado do Imperio do Brazil... anno de 1826. t. II. Rio de Janeiro, 1878. Sessão do dia 20 de junho. 
las (1768-1836), sem que se questionasse a centralidade do imperador, deveria privilegiar-se o sete de setembro, em que ele "quebrou as nossas prisões, as cadeias que nos ligavam a Portugal". Travava-se uma disputa em torno do aspecto do passado a destacar. Se sua figura se fazia central na narrativa que se afirmava como oficial, a representação do rompimento com Portugal também se impunha como evento fundador da nacionalida$\mathrm{de}^{24}$.

$\mathrm{Na}$ segunda discussão do projeto, Barbacena e o barão de Cairu (1756-1835) propuseram que se comemorasse apenas o 12 de outubro ${ }^{25}$. Não havendo acordo, adiou-se novamente a decisão. Retomando a palavra no segundo dia da terceira discussão, Nazaré, reagindo a tal proposta, afirma que havia

uma razão política em apoio dessas diversas festividades; é para que nossos filhos e netos, geralmente falando, as futuras gerações, ouvindo as salvas, vendo embandeiramentos e mais demonstrações de regozijo, próprias de semelhantes dias, se lembrem dos gloriosos fatos que neles se passaram.

Tal aspecto se fazia ainda mais importante quando se considerava que se lidava com um país de recente fundação. Determinar tais marcos narrativos e celebrativos seria, para o Brasil, um dever - pensando no interesse e na perspectiva da posteridade:

se nós já estivéssemos há séculos constituídos, não pugnaria tanto. Mas nós principiamos agora; tratamos de uma monarquia nova; de um novo império. É agora que nos constituímos e é impossível que as gerações futuras nos não cunhem de ingratos [...]. Com razão dirão elas que fomos mesquinhos em deixar de marcar dias que deviam ser assinalados com distintos e indeléveis caracteres da nossa gratidão ${ }^{26}$.

24 - Sendo reconhecido, em 1823, como momento fundador foi até 1831 considerado menos importante que a aclamação de D. Pedro, entendida como dia da criação oficial do império. KRAAY, H. “A invenção do Sete de Setembro, 1822-1831”. Almanak Braziliense, São Paulo, n. 11, 2010.

25 - O dia apresentava um duplo aspecto em torno do imperador: se festejar sua aclamação poderia reforçar a ideia da origem popular de seu poder, agradando aos mais radicais, celebrar seu nascimento como data de fundação do império agradava mais aos conservadores. KLAAY, H. Days of national... p. 41.

26 - Annaes do Senado... ano de 1826, t. III. Sessão do dia 17 de julho. Grifos meus. 
Tratava-se de uma espécie de obrigação de memória e de instrução frente às gerações futuras (sempre julgadoras). O que retoma algumas das questões apresentadas no início deste texto sobre a passagem do tempo percebida como interação entre gerações; supondo-se que os homens do presente/futuro tanto podem aprender com aquilo que os homens do presente/passado lhes legaram (memórias, patrimônio, benfeitorias), dando-lhes desenvolvimento crítico adequado (no caso da perspectiva histórica), quanto sentenciá-los negativamente com base no que eles deixaram de fazer ou fizeram de maneira indevida. Além da representação e da instrução coetâneas, portanto, tinha-se em vista como tais celebrações, reavivando a lembrança de aspectos do presente/passado, desempenhariam um papel na e para a posteridade, imbricando-se e fazendo dialogar (idealmente) diferentes estratos de tempo sob a perspectiva de um juízo da história.

Cairu, reagindo a uma proposição de Caravelas (que destacou a importância educativa das festividades - dado que "a maior parte da nação consta de homens que não folheiam livros"; homens que, em suas palavras, não "têm a história"), mostra-se supostamente otimista acerca da divulgação da narrativa mais tradicional, com base nos esforços das políticas imperiais:

foi dito por um ilustre senador que a maior parte do povo não lê, nem é capaz de ler a história da nação para se lembrar das referidas épocas notáveis, porém que se recordará sempre de ver e ouvir as festas nacionais. Digo que a constituição tem destinado a instrução pública a todo o povo e não é impossível que a das primeiras letras chegue a todas as classes.

Ele apresenta uma interessante ideia acerca da relação das populações com a narrativa histórica - em diferentes manifestações, densidades e suportes -, sugerindo a noção de instrução também por rituais quotidianos e por associação de ideias:

não se precisa que os indivíduos tenham livros in folio da historia nacional. Os factos principais, e especialmente das recomendadas e recomendáveis épocas, se podem todos os dias ler na cartilha religiosa 
e civil. Enfim, todas elas são subordinadas, ainda que pela associação de ideias, reunidas na festa nacional de 12 de Outubro, que será a nossa grande olimpíada ${ }^{27}$.

Numa altura em que se buscava afirmar a nação, concedia-se grande relevo ao discurso que se construía sobre a consolidação de sua independência, sobre a fundação de suas principais instituições e também sobre os indivíduos que desempenharam papel importante em tempos pretéritos. O debate parlamentar em torno do calendário indicia a relevância atribuída à preservação e à conformação da memória nacional. As festividades cívicas, para alguns, deveriam ter lugar cimeiro na pedagogia sobre o passado nacional - visto que instruíam e reavivavam tal memória pela via dos sentimentos. Para outros, contudo, a primazia caberia à história in folio (narrativa escrita sobre esse passado), auxiliada quotidianamente por práticas que transmitissem diferentes aspectos do discurso acerca do percurso da nação.

Tais preocupações, a partir de finais da década de 30, são consideradas e elaboradas de forma distinta no IHGB. No Instituto, com iniciativas e suportes diferentes, selecionam-se, elaboram-se e preservam-se documentos para a futura escrita da história (para a qual também estruturam-se parâmetros). Não se trata, pois, de mera narrativa sobre o passado nacional (um "testemunho", diria Macedo), mas do almejado discurso crítico, documentado e disciplinado sobre esse passado. Na instituição, ademais, além de se destacarem mais as continuidades que os rompimentos na relação passado-presente ${ }^{28}$, elabora-se uma espécie de panteão de papel relativamente aos indivíduos cuja memória julga-se importante preservar ${ }^{29}$.

27 - Annaes do Senado... ano de 1826, t. III. Sessão do dia 17 de julho.

28 - Nas discussões sobre a narrativa da nacionalidade no IHGB, a independência só gradualmente vai ser abordada, superando o território do presente. MALEVAL, I, I. Entre a $\operatorname{arca} \ldots$, p. 18.

29 - “O 'panteão de papel' brasileiro, erigido pela Revista do IHGB e pelos numerosos dicionários biográficos publicados durante o reinado de dom Pedro II, [...] conforma-se às leis gerais que orientam a história do Brasil, como sucessão de fatos e como narrativa, e que foram definidas por Martius em nome do IHGB. O recenseamento dos grandes homens extrapola, além disso, o debate acadêmico. A administração da posteridade, por suas implicações sociais, produz o encontro da história com a memória, mistura os campos intelectuais e políticos". ENDERS, A. "O Plutarco Brasileiro...”, p. 41-42. 
Quanto ao pós-1822, a definição de um calendário cívico imperial (distinto daquele que regeu as festas coloniais) relacionava-se a diferentes perspectivas sobre a imagem da nação, visando a ensinar/divulgar aos brasileiros o passado e o presente do Império de que eles faziam parte. Instaurado o regime parlamentar, os representantes incumbiram-se da tarefa de estabelecer marcos memorativos do passado selecionado do país, sensíveis à relevância da memória para instruir e para mobilizar a população em meio aos esforços para a conformação de uma identidade nacional. Com a ocorrência de mudanças políticas, contudo, determinados episódios afixados no repertório comemorativo foram perdendo destaque, sendo suprimidos ou substituídos seus festejos respectivos.

O imperador foi personagem central no calendário cívico durante $\mathrm{o}$ Primeiro Reinado (1822-1831). Sua associação com a narrativa que se afirmava relaciona-se à mobilização de sua figura como fonte de legitimação, substituindo referências anteriores (com as quais, contudo, ele representava continuidades em termos familiares/dinásticos e cerimoniais). A percepção que os brasileiros dele faziam, no entanto, foi aos poucos se distanciando da de um herói da nacionalidade. A abdicação, legitimada a partir de ideias de teor liberal (que se opunham a medidas autoritárias tomadas por D. Pedro), pode ser percebida como o culminar de um processo de reação a um governo que contrariava os interesses da maioria. Processo esse que se associou à desvalorização da imagem do imperador, com redução de seu impacto simbólico e reavaliação de seu papel histórico.

No período que se seguiu, em oposição ao imperador que abdicou, passou-se a se celebrar o sete de abril, data de sua abdicação. Apresentou-se o episódio, então, como uma espécie de revolução em que os brasileiros, sem derramamento de sangue e desordens, puseram fim a um governo despótico. Assim, em 1831, discutiu-se e se aprovou um novo calendário nacional (decreto de 25 de outubro), em que se suprimia o 12 de outubro, adicionando-se, em contrapartida, o aniversário de D. Pedro 
II (dois de dezembro) e o próprio sete de abril ${ }^{30}$. Relembrada anualmente, a abdicação mobilizava a população sem contar com o apelo ao impera$\operatorname{dor}^{31}$.

Já em Portugal, entretanto, D. Pedro afirmou-se como comandante liberal, liderando, em favor de sua filha D. Maria II (1834-1853), tropas militares contra os absolutistas capitaneados por seu irmão D. Miguel e, com sua vitória, restaurando a Carta que ele mesmo outorgara. Bastante intensos, os embates marcaram fortemente a política do país, com a derrota dos miguelistas e o início da segunda experiência liberal portuguesa, que tinha no regente, o dador da Carta, uma figura fundadora ${ }^{32}$.

No Brasil, contudo, se no período inicial da Regência (1831-1840), de teor liberal moderado (até 1837), afirmou-se forte oposição a sua imagem enquanto uma espécie de déspota, as mudanças que caracterizaram o Regresso conservador emprestaram diferentes sentidos aos festejos que relembravam sua abdicação, ressignificando também sua imagem. Antes foco de intensa disputa, tal celebração foi esmorecendo, em um processo caracterizado pela alternância de grupo no poder ${ }^{33}$, em que também pesou a morte de D. Pedro, desalentando a oposição a sua figura e facilitando uma melhor apreciação daquela de seu filho/sucessor ${ }^{34}$.

30 - Annaes do Parlamento Brazileiro, t. II, 1831. Rio de Janeiro, 1878.

31 - Seus principais promotores eram os liberais moderados, organizados na Sociedade Defensora da Liberdade e da Independência Nacional (1831). FERNANDES, G. S. R. 7 de Abril: usos políticos e representações na Regência (1831-1840). Dissertação de Mestrado, História. Juiz de Fora: UFJF, 2013.

32 - SILVA, A. M. "A vitória definitiva do Liberalismo e a instabilidade constitucional: cartismo, setembrismo e cabralismo”. In: MATTOSO, J. (dir.) História de Portugal, v. V. Lisboa: Estampa, 1998, p. 77-81.

33 - " [...] além da luta pelo controle simbólico do espaço público, estava em jogo a construção de uma memória nacional acerca dos objetos alçados ao panteão cívico da pátria - a Constituição, a Abdicação, a Independência e o imperador Pedro II -, eles próprios eivados de controvérsias". BASILE, M. O. N. C. "Festas cívicas na Corte regencial". Varia História, Belo Horizonte, v. 22, n. 36, 2006, p. 513-514.

34 - Inicialmente apresentado como um movimento popular que resultara na abdicação, deixando o poder a cargo de uma regência ocupada por cidadãos, perdeu pompa, passando a pontuar o dia em que o trono fora entregue a D. Pedro II (1840-1889), cujo aniversário ganhou destaque. FERNANDES, G. S. R. 7 de Abril... Sobre a relação da narrativa do passado no Segundo Reinado com o imperador (mecenas do IHGB) e a ideia de conciliação com a herança portuguesa: GUIMARÃES, L. M. P. Debaixo da imediata... 
O processo de leitura e de releitura de episódios relacionados a D. Pedro I/IV implicava a elaboração de diferentes visões sobre sua pessoa e sobre seu legado. De herói da independência em favor dos brasileiros liberais (o que, em Portugal, era percebido como uma espécie de traição), ele passou a ser visto, no Brasil, como um déspota português cuja abdicação se celebrava. Na antiga metrópole, entretanto, afirmava-se sobretudo devido à liderança das tropas liberais, restabelecendo a Carta constitucional. Com o tempo e com as mais mudanças políticas, alterou-se também a percepção sobre seu papel histórico. Destacando-se em sua trajetória sobretudo que ele abdicara de duas coroas em favor de seus filhos, outorgara duas cartas constitucionais e lutara contra tropas absolutistas em Portugal (restaurando o liberalismo), sua imagem pôde ser recuperada e novamente celebrada - ainda que tal recuperação enfrentasse questionamentos e oposições nos dois países ${ }^{35}$.

De modo geral, tais festejos seguiam rituais conhecidos da população nos dois lados do Atlântico. Envolviam iluminações, fogos-de-artifício, tiros de canhão, hinos, representações teatrais e cerimônias religiosas. Ocupando o espaço público e alterando a rotina quotidiana, imbricavam manifestações políticas e religiosas. Além dos debates em torno de seu estabelecimento, as comemorações repercutiam nos jornais da época - em meio a conclamações, a críticas e a descrições. Tratava-se, portanto, de disputas narrativas em torno da construção da mensagem que se esperava afirmar tanto com celebrações quanto com os relatos a seu respeito (espécie de memória das memórias então ritualizadas); relatos que se divulgavam à altura e que hoje são importante fonte para historiadores ${ }^{36}$.

Ainda nas primeiras discussões sobre o calendário cívico imperial, expressaram-se diferentes formas de mobilizar discursos sobre o passado

35 - LAW, D. The legacy of Brazil's Pedro I: memory and politics during the empire and republic. Dissertation, Doctor of Philosophy. Baltimore: Johns Hopkins University, 2015. Aborda-se como se lidou com o legado de D. Pedro no Brasil, incluindo sua reabilitação no Segundo Reinado, atribuída em grande parte a seu histórico em Portugal. Para Portugal: CATROGA, F. O culto...

36 - Para o Brasil: KRAAY, H. Days of national... E Portugal: ANDRADE, L. O. \& CATROGA, L. R. Feriados... 
- em livros, em festividades, em monumentos, em jornais. Valendo-se da evocação de sentimentos, visava-se a cumprir expectativas quanto ao julgamento de gerações futuras (relacionadas à preservação da memória e ao registro de vestígios do presente e também de grandes homens e marcos do passado). Ademais, relativamente ao momento em que viviam e a suas demandas específicas, buscava-se instruir sobre o Império sua população iletrada. Nas palavras de Caravelas:

disse o ilustre senador [Cairu] que a história fará a devida comemoração deles [os episódios em disputa]; mas eu pergunto se pela história se faz que, quando chegar o aniversário de um desses dias, a nação se sensibilize e entusiasme, como sendo de festividade? Decerto que não, porque não há um objeto que lhe desperte a memória desse dia, nem dos fatos nele acontecidos. Pergunto mais: a nação toda compõe-se de homens que têm a história? Não; a maior parte da nação consta de homens que não folheiam livros, uns porque lhes falta o tempo, outros porque não sabem ler. Os antigos, para eternizarem estes dias, levantavam monumentos e até os gravavam em bronze, para não se esquecerem. Nós não fazemos o mesmo, tão frequentes vezes, porque temos a imprensa, com que suprimos esses monumentos e esses bronzes. Mas é necessário que haja a festividade nacional, porque o povo, em geral, não lê a história, como já disse, mas vê a festividade e então pergunta ao instruido na história o motivo dela, e este lho explica. [...] É verdade que nossos vindouros não experimentarão nesses dias os mesmos sentimentos que nós agora experimentamos. Entretanto, sempre se conservará a lembrança deles. ${ }^{37}$

Nota-se seu otimismo quanto ao potencial dos impressos (monumento em papel) na conformação da narrativa nacional (história in folio) contra o esquecimento, o que, contudo, não descarta a percepção da importância das festividades enquanto estratégia para despertar a memória, sobretudo tendo em conta que a maior parte da população não conhecia essa narrativa. De modo a mobilizar e a instruir civicamente tais indivíduos, as festividades apelariam para seus sentimentos, cabendo aos poucos instruídos - que conheciam a história in folio -, explicar-lhes os motivos por trás das cerimônias (que amplificavam e animavam essa mesma nar-

37 - Annaes do Senado ... ano de 1826, t. II. Sessão do dia 17 de julho. Grifos meus. 
rativa). Ao se recuperarem e ao se reunirem discursos destoantes em torno do estabelecimento de datas e de cerimônias comemorativas, busca-se ressaltar as disputas acerca desses usos do passado (selecionado e encenado coletivamente) $)^{38}$ - indício de sua relevância para os envolvidos.

\section{Do passado, do futuro}

Mantendo o foco nas comemorações históricas, uma vez mais cruza-se o Atlântico, avançando no calendário até a década de 80 do século XIX - "o 'século da História', porque foi igualmente o 'século do culto dos mortos" "39. Parte-se, neste passo do texto, de leituras sobre o centenário da morte do marquês de Pombal (1699-1782), que agitou ruas e impressos em Portugal e no Brasil em $1882^{40}$. As mobilizações para festejar a efeméride iniciaram-se em 1881, sendo não apenas relatadas, mas também apreciadas de formas diversas em periódicos coetâneos. Lê-se, assim, em um jornal católico ainda em outubro:

nos custa revolver a história de Sebastião José de Carvalho e Mello e apresentar à luz da publicidade as numerosas crueldades que o seu gênio ou os costumes do seu tempo o levaram a praticar e mais nos custa ainda por sabermos que os descendentes do marquês de Pombal cons-

38 - Para Marc Ferro (A História Vigiada. Rio de Janeiro: Martins Fontes, 1989 [1985], p. 54-60), "a comemoração acusa os silêncios, desloca os fatos e os seleciona. Como a narrativa histórica, ela é um ponto de conflitos". De acordo com Oliver Ilh ("Commemoratio", L'Observaroire, n. 50, 2017, p. 12), pode-se falar de comemorações como mise en scène; ritos, símbolos e manifestações evocando um passado reivindicado no presente. Durval Muniz de Albuquerque Jr. (O tecelão dos tempos. São Paulo: intermeios, 2019, p. 179-189) entende que a comemoração é "atravessada e constituída por um enredo, é uma forma de fazer ver e de dizer o passado. [...] põe em cena, torna visível, materializa dadas memórias, dadas versões e visões do passado [...] como a narrativa histórica, cria efeitos de real, apoia-se em vestígios, testemunhos, em outras narrativas que chegam do passado para construir versões verossímeis sobre o que teria ocorrido [...] é, por fim, um dos usos que se pode fazer do passado".

39 - CATROGA, F. O céu da memória ... p. 315.

40 - Ver, deste autor: PEREIRA, G. "Passado em papel-jornal: Pombal, 'A Folha Nova' e 'A Palavra' - impressões em disputa no centenário do marquês (Porto, 1882)". Temporalidades - revista de história, v. 11, n. 2, 2019. Os embates em torno do centenário pombalino de 1882, dos dois lados do Atlântico, são o ponto de partida da tese de doutorado (História, Universidade Nova de Lisboa) em elaboração, intitulada Os "homens do futuro" e o passado pombalino: representações do marquês nas comemorações do primeiro centenário de sua morte. 
tituem uma família das mais respeitáveis do nosso país [...]. E seria bastante o respeito que como católico devemos a essas nobilíssimas pessoas, para deixarmos em paz, no silêncio do túmulo e na vida eterna, o corpo e a alma do homem de que nos temos ocupado em vários artigos. Mas o cinismo com que a Revolução e os seus homens quer fazer alarde do quanto adora o marquês de Pombal pelo fato único de ser o algoz da Companhia de Jesus impele-nos a pena e obriga-nos a apresenta-lo à luz pública com todas as suas crueldades, com todos os seus despotismos ${ }^{41}$.

Em outro jornal católico, já durante os festejos, lê-se mais uma crítica à recuperação da figura histórica do marquês:

se o horror que os demagogos professam à tirania e aos tiranos fosse sincero e verdadeiro, deixariam esquecidos debaixo do pó dos séculos o marquês de Pombal e diriam com muito bom senso: as tiranias e prepotências daquele malvado, daquele déspota foram superiores, e muito superiores, a algumas obras boas que fez e portanto o seu nome deve ser esquecido e até detestado por aqueles que amam sinceramente a liberdade ${ }^{42}$.

Diferentemente da reflexão sobre meios para se contornar o esquecimento - pela via da comemoração e por diferentes suportes para a narrativa histórica -, tais críticos (católicos) da homenagem a Pombal (de teor republicano) sugerem não só a interdição de uma temática polêmica considerada ainda próxima do presente, mas também a conveniência de se esquecer um passado percebido como assaz negativo.

Opondo-se à iniciativa sob justificativa diferente e abordando a própria apreciação e veiculação desse passado, o célebre Camilo Castelo Branco (1825-1890) publica, em Portugal e no Brasil, uma obra crítica a Pombal e a seus apologistas, acerca da qual afirma: "este livro poderia ter aparecido antes dos festejos [...]. Seria, então, um protesto contra o entusiasmo dos propugnadores do marquês de Pombal". No entanto, abstém-se "dessa aspiração vangloriosa que teria uns ares desvanecidos de querer atuar sobre convicções radicadas [...]. Seria, sobre infrutífera,

41 - O Progresso Católico (1878-1925), Guimarães, 30/10/1881.

42 - A Palavra (1872-1911), Porto, 11/05/1882. 
ridícula a empresa". Afinal, comparando seu esforço de mobilização e sua estratégia de narrativa com os de seus opositores, pondera:

não se desfazem com os livros as persuasões que se fizeram com locais de jornais baratos [...]. A porção do povo que não aprende nada em livros achou nos clubes a educação do discurso amoldado à sua capacidade, à sua dócil ignorância e à sua congenital necessidade de revolucionar-se com palmas e gritos [...]. Crenças assim radicadas e cáusticas não se acalmam com cataplasmas de livros ${ }^{43}$.

Trata-se tanto do contraste entre públicos, limitações e potenciais/ efeitos instrutivos da história in folio e da narrativa histórica ritualizada em manifestações/festividades públicas quanto da diferenciação entre suportes dessa escrita, nomeadamente livros (que, como jornais supostamente mais sérios, disporiam de um público leitor seleto) e imprensa "barata" (bastante mais popular, e também depreciada). Quanto aos clubes, foram os primeiros núcleos republicanos em Portugal, apenas lentamente desenvolvendo-se formas próximas de organizações partidárias. Os republicanos portugueses reuniam-se em associações que, proibidas de ostentar fins políticos, realizavam atividades de fundo cultural, instrutivo, recreativo e de auxílio mútuo. Outra empresa a que dedicavam esforços, abordando temáticas de teor histórico, político e cultural, era o jornalismo, dado seu potencial de divulgação e de instrução ${ }^{44}$.

43 - Perfil do marquês de Pombal. Porto/Rio de Janeiro, 1882, proêmio. Ver: PEREIRA, G. "O 'Perfil do marquês de Pombal' e as disputas em torno das impressões sobre o passado pombalino". ANPUH. Anais do 30 Simpósio Nacional de História. Recife, 2019. 44 - CATROGA, F. O republicanismo em Portugal: da formação ao 5 de outubro de 1910. Lisboa: Casa das Letras, 2010 [1991], p. 18-20, 30-35. A história era assunto de conferências e de colóquios republicanos; fonte de argumentação, mobilizada na conformação identitária. Com grande influência de ideais positivistas e cientificistas, o pensamento historiográfico republicano não foi uníssono; comportava leituras e referências teóricas diversas. RIBEIRO, L. A popularização da cultura republicana, 1881-1910. Coimbra: Universidade de Coimbra, 2010, p. 142-147. Sobre os centenários em Portugal: JOÃO, M. I. Memória e Império: Comemorações em Portugal (1880-1960). Tese de Doutorado, História. Lisboa: Universidade Aberta, 1999. 
Em Portugal (e também no Brasil) ${ }^{45}$, na sequência de comemorações na Itália (Petrarca, 1874) e na França (Voltaire, 1878), celebra-se, em 1880, o centenário de Camões, festejado enquanto herói da língua e da nacionalidade portuguesas, sendo a memória a seu respeito politicamente mobilizada em prol da revivescência nacional. Os festejos camonianos, considerados um sucesso, servem de modelo aos pombalinos aqui em pauta (muito mais polêmicos). Em ambos, pelas mobilizações e pelas iniciativas, destacam-se os republicanos, que ganham visibilidade devido a seu engajamento nessas comemorações (e também em outros protestos nacionalistas), mobilizando memórias para sua crítica política.

Nesses festejos, relacionados ao calendário pela efeméride dos cem anos de episódios selecionados (como a morte de grandes homens do passado), nota-se a influência de um positivismo de matriz comtiana não-ortodoxa, concebendo-se as sociedades e seu desenvolvimento a partir da ideia de um progresso determinado, informado pela sociologia positiva. Na comemoração dos centenários republicano-positivistas, apresentam-se discursos sobre o passado em conferências, em publicações, em cortejos cívicos e em outras manifestações, para homenagear indivíduos que teriam desempenhado devidamente seu respectivo papel histórico (concebido teleologicamente) - valendo-se de sua memória (reelaborada) para a crítica política ${ }^{46}$.

45 - A colônia portuguesa contou com grande apoio dos brasileiros. Em Paris, os festejos foram conduzidos pelo brasileiro Miguel Lemos (1854-1917). PAREDES, M. M. Configurações luso-brasileiras: fronteiras culturais, demarcações da história e escalas identitárias (1870-1910). Sarbruque: Novas Edições Acadêmicas, 2013, pt. II.

46 - Não se pensava a exemplaridade inserindo-se os acontecimentos em totalidades finitas, sem que uma lógica autossuficiente comandasse o devir universal - como nas filosofias da história. Nessas, os grandes homens, emanações subjetivas da consciência da nação/humanidade, são percebidos como quem (mesmo sem se dar conta dos efeitos de suas ações) pôs em prática o "espírito de seu tempo", atendendo a suas demandas. Para julga-los devidamente, era necessário levar em conta o sentido do progresso. Para o que aqui importa, remete-se à sistematização realizada por Auguste Comte (1798-1853) e continuada por positivistas de diferentes matizes em Portugal e no Brasil. CATROGA, F. “Ainda será a História Mestra da Vida?”, Estudos Ibero-Americanos, n. 2, 2006, p. 13, $25-26$. 
Se a comemoração camoniana evoca as glórias dos descobrimentos (que o poeta cantou), potencializando críticas à decadência da antiga potência colonial, a proposta dos festejos pombalinos relembra as medidas reformistas do marquês (sobretudo em relação à instrução e às ordens religiosas), potencializando demandas concretas por sua atualização, sentido que o programa-manifesto da Academia de Lisboa (1878), iniciadora das comemorações de Pombal, explicita. Os estudantes, afinal, após exaltarem as reformas pombalinas do ensino, reforçam a continuidade que desejavam estabelecer entre as políticas que reclamavam em 1882, o liberalismo de 1834 (que, reivindicando a influência pombalina, atualizou medidas anticongreganistas) e o pombalismo de 1759 , pedem ao poder executivo "o cumprimento exato dos decretos [...] a respeito de todas as ordens religiosas" ${ }^{\prime \prime}$. Estabelecem-se relações entre diferentes passos do passado e o presente corrente - visando à concretização de projetos políticos que informavam um futuro determinado.

No Brasil, onde se ecoou e se imprimiu o documento da Academia, os estudantes da capital, entre iniciativas em outras localidades e conferências que remontam a 1881 , reúnem-se em um congresso deliberativo, respondendo positivamente a um convite feito por seus congêneres portugueses. Realizam subscrições públicas para remeter valores a Portugal e também recolhem esmolas pela alforria de escravos. A maior iniciativa no Rio de Janeiro, contudo, parte do Club de Regatas Guanabarense (1874), que promove cerimônias formais, festejos e impressos de teor histórico.

Na cidade, a polêmica instaura-se sobretudo nos jornais, que divulgam diferentes leituras sobre a influência do governo pombalino no passado do país. Entre outros aspectos, os promotores do centenário esforçam-se por fazer ver um Pombal precursor de medidas abolicionistas - como o que transparece no discurso de Rui Barbosa (1849-1923) no sarau literário-musical realizado no teatro imperial Pedro II, ponto alto

47 - O programa foi referido em diversos periódicos na íntegra ou em trechos; elogiosa ou criticamente, como no de maior circulação no país: Diário de Notícias (1864-presente), Lisboa, 04/03/1882. 
das festas ${ }^{48}$. Quanto ao IHGB, o marquês, só em 1982, vai ser objeto de homenagens póstumas na instituição, mediante a realização de uma série de palestras acadêmicas ${ }^{49}$.

Em Portugal, as festas pombalinas, dadas as paixões do passado trazidas à tona, estão bastante longe de um consenso ${ }^{50}$. A esse respeito, cita-se um relato da discussão na câmara dos deputados em 17 de abril ${ }^{51}$ :

O sr. [José] Dias Ferreira [1837-1909] entende que o governo deve prestar um subsídio aos festejos do centenário de iniciativa dos estudantes, que o governo parece querer empalmar. O marquês de Pombal nunca pode ser encarado como incolor em política ${ }^{52}$, porque a sua principal feição foi o caráter político de que revestiu os seus atos. A sua principal glória foi libertar o país e o rei da influência jesuítica, que disseminava as trevas. Entre nós está determinada a expulsão dos jesuítas e a extinção dos conventos das freiras, e contudo os jesuítas e as freiras ainda continuam. [...] Envia para a mesa uma proposta para que se tenha em atenção a legislação pombalina acerca dos jesuítas.

O sr. Luciano Cordeiro [1844-1900] diz que a festa é nacional, mas que só poder ser fazendo-se abstração de atribuir ao marquês de Pom-

48 - BARBOSA, R. Centenário do marquês de Pombal. Discurso pronunciado a 8 de maio... Rio de Janeiro, 1882.

49 - Em 1980, Joaquim Veríssimo Serrão (sócio-correspondente do IHGB e presidente da Academia Portuguesa da História) sugere a conveniência do festejo do bicentenário, com uma possível parceria entre as instituições (R.IHGB, n. 329, p. 244). O assunto volta à revista em 1981 (n. 333, p.179), quando se relata que Carneiro de Mendonça (18941988) comunica em julho sobre futura comemoração no ano seguinte, e já em 1982 (n. 337 , p. 249, 272), apontando-se que ele realizara uma série de palestras sobre Pombal "cujo $2^{\circ}$ centenário de morte vem sendo comemorado no decorrer deste ano". Relata-se, ainda, que o bicentenário "foi lembrado desde atrás em reuniões da CEPHAS, sobretudo pela voz de seu presidente, Marcos Carneiro de Mendonça, para o qual o Brasil muito ficou a dever à administração pombalina".

50 - BEBIANO, R. "O $1^{\circ}$ centenário pombalino (1882). Contributo para a sua compreensão histórica". Revista de História das Idéias. Coimbra, v. 4, t. II, 1982.

51 - O envolvimento do governo regenerador oficializa-se em fins de abril. Dado o teor republicano e crítico assumido do centenário camoniano, realizado sob um governo progressista, espera-se controlar e esvaziar o teor crítico dos festejos pombalinos. Os estudantes tentam resguardar suas prerrogativas. Após polêmica, nomeia-se uma comissão mista, com deputados, com membros do governo e com acadêmicos.

52 - Grifo meu. A expressão ecoa a forma como o lisboeta O Diário de Notícias se apresentava. Seus opositores o apontavam ironicamente como o incolor, acusando não a neutralidade política pretendida com a expressão, e sim suas parcialidades quotidianas. 
bal a glória de expulsar os jesuítas. O marquês de Pombal tem muitos títulos de glória, este é que não parece que o seja. Receia que os jesuítas digam que somos ignorantes em história, pois que foi ele quem em Portugal levou o absolutismo ao seu requinte, e que deu à inquisição o caráter oficial Uma festividade não pode ser nacional logo que todos, por qualquer circunstância nela, se não associem a ela.

O sr. [Emídio Júlio] Navarro [1944-1905] nota as contradições do discurso do sr. Luciano Cordeiro [governo]. Ou o marquês de Pombal é digno de merecer uma manifestação de respeito e admiração ou não é. Se é, não é dado deturpar-lhe as feições. O fato mais saliente da sua vida é a guerra pertinaz movida contra os jesuítas ${ }^{53}$.

Os deputados ocupam-se de estabelecer como conduzir a questão e as releituras sobre o passado pombalino, debatendo, inclusive, o que destacar ou o que abstrair - já que a iniciativa festiva, as conferências e os textos já haviam levado sua memória para o debate público. A questão entra no parlamento em quatro de março, quando Augusto Fonseca Coutinho (1857-1887) apresenta uma proposta para que o governo secundasse os organizadores dos festejos, introduzindo-a com as seguintes palavras (elucidativas sobre a ideia das apoteoses como dever cívico):

a antiguidade tornava deuses os seus heróis. Era uma consagração sob uma forma sobrenatural e misteriosa. Mas o culto de ontem tem a mesma significação que o culto de hoje, que se reveste de um aspecto humano.

É sempre o respeito, é sempre a adoração pelos homens que foram grandes, que baixaram ao túmulo estreito tendo enchido com seus nomes a eternidade dos séculos e que ainda lá do seu nada ensinam e são glória para as nações, como Sebastião José de Carvalho e Mello, o famoso marquês de Pombal, é título glorioso para a nacionalidade portuguesa.

Todas as nações cultas celebram hoje em centenários a memória dos seus imortais e nós já nos compenetramos desse dever cívico dando à Europa, pela festa a Camões, um testemunho evidente da nossa vida de progresso.

É mister, pois, que a nação que nós aqui representamos vá secundar todos os beneméritos esforços que tão nobremente se estão manifes-

53 - O Século (1881-1983), Lisboa, 18/04/1882. 
tando, não deixando entregue exclusivamente à iniciativa particular a comemoração do centenário do marquês de Pombal, porque é uma festa de todos nós, da nação portuguesa ${ }^{54}$.

Na referida sessão de 17 de abril, quando o governo apresenta sua proposta, Alberto de Almeida Pimentel (1849-1925) demarca-se da forma como se conduz a questão:

não tenho um grande entusiasmo pelo centenário do marquês de Pombal; $[\ldots]$ acho ainda muitíssimo cedo para qualquer solenidade públi$\mathrm{ca}$, para qualquer demonstração de aplauso nacional [...] se os mortos passam depressa, muitas vezes, para a nossa saudade, se desaparecem rapidamente na sua bailada fantástica a caminho da eternidade, os legisladores vão devagar, vergados ao peso das suas próprias responsabilidades, como se lhes pesasse sobre os ombros o enorme lenho da história, que é, ao mesmo tempo, uma cruz e uma glorificação.

E tanto isso é verdade, que eu entendo que as responsabilidades políticas do marquês de Pombal não estão ainda perfeitamente liquidadas. $[\ldots]$

Não posso afirmar à câmara se o dia 8 de maio irá ou não cobrir de luto muitas famílias; mas a prova de que as paixões estão ainda muito vivas e acesas é que alguns dos conferentes que se têm ocupado do assunto do centenário do marquês de Pombal têm ouvido, por entre o ruído das ovações, corajosas demonstrações de desagrado.

Evocando uma necessária distância temporal para melhor apreciar o governo pombalino, ele considera prematura a iniciativa do parlamento (que deveria reger-se por outro ritmo; de modo mais sensato, sob o "lenho da história") e acusa algumas das reações públicas contrárias à homenagem póstuma. O deputado, ademais (em sentido parecido com o das críticas do visconde de Barbacena, que em 1826 exageradamente acusava o risco de as festividades ocuparem metade do calendário), denuncia uma suposta profusão de centenários, apresentando uma lista de futuras e hipotéticas apoteoses por efemérides que chegam a 1993. Para ele, era preciso

pôr cobro a essa paixão pelos centenários e pelos monumentos, que já se vai tornando demasiadamente extensa. [...] Nós vamos ter cen-

54 - Diario da Camara dos Senhores Deputados. Sessão de 4 de março de 1882. 
tenários por muitos anos. Até será fácil organizar um calendário sob esse ponto de vista ${ }^{55}$.

Teófilo Braga (1843-1924), professor do Curso Superior de Letras e um dos iniciadores do positivismo em Portugal, é uma boa referência para compreender como os estudantes lisboetas (por ele influenciados), ao apreciarem o governo pombalino, entendem poder a um tempo prever o futuro e teleologicamente julgar o passado. Refletindo sobre os centenários de Camões (de que foi promotor) e de Pombal, ele afirma que o primeiro contava com a simpatia por sua personalidade, reconhecendo-se facilmente sua contribuição histórica.

Quanto ao segundo, "se entramos nas circunstâncias da sua personalidade, na consideração dos meios de que se serviu para realizar as grandes reformas, acham-nos sem simpatia por ele [...] não o podemos glorificar com amor". Para Teófilo, contudo, "a justiça para com os vultos históricos como Pombal não consiste em atenuar-lhes as ações com sofismas retóricos, nem calar os meios mais ou menos duros com que exerceram o domínio; basta simplesmente que os restituam à sua época e que se ponha em evidência o seu destino". A partir da ideia de que ele desempenhou um papel histórico importante e necessário para o progresso do país, Teófilo aponta seu centenário como "o grande e imparcial julgamento de um século" 56 .

Também positivista e professor na referida instituição, Consiglieri Pedroso (1851-1940) concorda com a avaliação de Teófilo sobre o marquês. Comparando os dois centenários, contudo, ele adia para a posteridade seu devido julgamento - dados os necessários, mas violentos meios de que Pombal se valera para desempenhar seu papel histórico, que ainda despertavam paixões e ressentimentos. Quanto a Camões, ele já estava, à altura,

demasiado longe e ao mesmo tempo demasiadamente alto para que dele nos chegue outra coisa que não seja o que é imortal, o que é

55 - Diario da Camara... Sessão de 17 de abril de 1882. Grifos meus.

56 - BRAGA, J. T. F. Os centenários como síntese afetiva nas sociedades modernas. Porto, 1884, p. 185-190. 
divino como cintilação do gênio. Quem se lembraria de ir hoje desentranhar, da poeira dos arquivos, pequenos senões que podem lançar uma leve sombra no caracter do poeta? Pelo contrário, Pombal, no desempenho da sua espinhosa missão, teve de esmagar interesses que são ainda de ontem; teve de abrir feridas que ainda hoje sangram; teve de passar por cima de considerações que ainda neste momento se levantaram para protestar.

[...] Pombal aparece-nos, por um lado, anda muito perto - apenas a um século de distância - e, pelo outro, demasiadamente envolvido na luta que ele travou com a sociedade do seu tempo, para que, com a serenidade do julgador, todos nós possamos fazer-lhe a justiça que lhe é devida.

[...] passe-se mais um século e quando todas as antipatias, todos os ódios, todos os rancores tiverem caído perante uma critica mais imparcial e mais equitativa; quando a geração de então tiver aprendido a ser mais justa com as gerações do passado que lhe prepararam o advento, nós estamos certos de que Portugal, procedendo à revisão do processo histórico do marquês de Pombal, há de, sem discrepância de um único de seus filhos, saudar a memória do grande homem que, nos fins do século XVIII, teve forças para abrir, com pulsos de ferro, um luminoso parênteses no meio da profunda decadência da nossa pátria $^{57}$.

Castelo Branco, por sua parte, valendo-se de um exercício de previsão tão ao gosto dos positivistas, mas de modo sobretudo irônico, questiona a validade das iniciativas centenárias, pondo em dúvida a própria ideia de se analisar e de se elogiar teleologicamente o passado. Ele afirma, pois, criticamente:

daqui a pouco, nós e os nossos centenários e a estéril inanidade das nossas solicitações ruidosas ao Futuro, iremos na ressaca da mesma onda que virá colher o cisco da nossa Babel e bem pode ser que o jesuíta, renascido do seio de outra civilização, surja depois para rir de nós. Se os ultraliberais de 1882 estão com o marquês de Pombal, quem nos afirma que as confederações republicanas e ateístas de 1982 não hão de estar com os jesuítas? As situações parecem-me equivalentes nas paralelas do absurdo ${ }^{58}$.

57 - O Occidente (1878-1915), Lisboa, 05/08/1882. Grifos meus.

58 - BRANCO, C. C. Perfil do marquês...proêmio. Grifos meus. 


\section{Do futuro, do passado}

Apontou-se, ao longo deste texto, como, no Oitocentos, considerava-se necessário um distanciamento cronológico e afetivo para a justa apreciação do passado - o que implicava uma série de interditos à crítica histórica, por se entender que apenas aos historiadores do futuro caberia o julgamento de questões polêmicas/candentes. Apontou-se, ainda, como, para contornar o esquecimento, coligiam-se vestígios e testemunhos do passado (e também do presente) e se reavivam memórias sobre homens e sobre episódios pretéritos - viabilizando a futura escrita/crítica da história e também mobilizando e instruindo a população. Apontou-se, por fim, como mudanças políticas e a crítica/escrita da história paulatinamente conformavam diferentes pontos de vista sobre indivíduos e sobre acontecimentos e como muitas cerimônias oficiais, mesmo passando por uma série de revisões, foram perdendo sua eficácia, confrontadas por iniciativas diversas.

Seja pelas diferentes perspectivas sobre seu histórico em Portugal e no Brasil (expressas em narrativas e comemorações oficialmente estabelecidas e atualizadas nas décadas de 20 e 30), seja pelo descrédito relativamente à forma como se esperava mobilizar e reavivar sua memória (já na década de 80 , quando, além da crítica histórica concebida em termos variados, propunham-se comemorações de um tipo diferente), o caso de D. Pedro permitiu desenvolver algumas das reflexões propostas. $\mathrm{O}$ de Pombal, por sua parte, levantou outras considerações. Cem anos após sua morte, para alguns, ainda era demasiado cedo para apreciar e para evocar seu histórico. Já para outros, seria melhor não reavivar sua memória - condenando-o ao esquecimento (essa "segunda e mais irremediável morte"). Para os promotores do centenário, entretanto, mesmo que a possibilidade da devida compreensão de seu papel histórico se encontrasse na posteridade (por isso muitos não lograriam avaliá-lo devidamente), não se fazia necessário adiar ainda mais seu derradeiro julgamento. Imbuídos de ideais positivistas, afinal, era a partir da posteridade que eles apresentavam suas supostas credenciais de árbitros da história. Em sua 
crítica futurante, julgavam o passado pombalino teleologicamente; em função do futuro que entendiam prever e encarnar.

De modo a arrematar este percurso reflexivo sem pretensas conclusões, retomam-se, sob nova luz, as palavras reproduzidas na epígrafe deste texto. São versos eloquentes; espécie de síntese entoada pelos estudantes lisboetas nos festejos pombalinos por eles capitaneados. Imaginem-se, pois, os rapazes. As principais ruas da capital, enfeitadas com flores, estão apinhadas de gente curiosa. Com seu carro alegórico, com suas bandeiras e com seus estandartes, os acadêmicos destacam-se em um grande cortejo. Percorrendo a cidade em festa, eles cantam, orgulhosos, seu hino-manifesto, declarando a seus (arcaicos) contemporâneos:

Nós, os homens do futuro

[...] herdeiros e discípulos

De Camões e de Pombal Empunhando a pena ou a espada Honraremos Portugal ${ }^{59}$.

Texto apresentado em julho de 2019. Aprovado para publicação em outubro de 2019.

59 - ALMEIDA, A. M. F. Hino dos estudantes adotado no programa do centenário do Marquês de Pombal, reformador dos estudos, reedificador de Lisboa etc. etc. Lisboa, 1882. 